\title{
Frágeis fronteiras: relatos testamentais de mulheres das Minas Gerais setecentistas $1 /$
}

\author{
Fragile Frontiers: Testamentary Stories \\ of Women in XVIII-Century Minas Gerais
}

\author{
Eduardo França Paiva
}

Universidade Federal de Minas Gerais, Brasil

Durante o período colonial, nas Minas Gerais, as mulheres forras, seguidas pelas livres (brancas e mestiças) legaram ao futuro uma quantidade nada desprezível de testamentos. Nesses documentos, aparecem registrados relatos feitos oralmente por elas e transcritos por algum escrivão, bem como impressões, gostos, declarações de toda natureza e, ainda, informações preciosas, intencionais ou não, sobre família, mestiçagens, ascensão e distinções sociais, sociabilidades, mobilidade física, social e cultural. Os discursos dessas mulheres sobre o viver naquele universo colonial, incluindo o que, por vezes, se pôde captar nas entrelinhas dos testamentos, constituem o objeto central do texto e são o ponto de partida do diálogo estabelecido com esses personagens setecentistas.

Palavras-Chave: Testamentos; Mulheres forras; Mulheres livres; Minas Gerais; Mestiçagens; Escravismo.

During the colonial period, in Minas Gerais, freedwomen, followed by the free ones (white and mestiza), bequeathed to the future a quantity not despicable of wills. In these documents, are registered reports done orally by them and transcribed by some notary, as well as impressions, preferences, declarations of all kinds of nature and, still, precious information, intentional or not, about family, miscegenation, ascension and social distinctions, sociabilities, physical, social and cultural mobility. The speeches of these women on living in that colonial universe, including what, for times, it was possible to read in the inbetween lines of the wills, constitute the central object of this text and are the starting point of the dialog established with these XVIII ${ }^{\text {th }}$ characters.

KEYwORDS: Wills; Freedwomen; free Women; Minas Gerais; miscegenation; Slavery

1 Texto produzido no âmbito do projeto Las fronteras y sus ciudades: herencias, experiencias y mestizajes en los márgenes del Imperio Hispánico (s. XVI-XVIII), aprovado pelo Ministerio de Educación y Ciencia de España, sob o número HUM2007-64126, dirigido pelo Dr. Salvador Bernabéu Albert e a partir de bolsa de pesquisa (Programa Formación Permanente. Movilidad profesores universidades públicas brasileñas) concedida pela Fundación Carolina, entre dezembro de 2007 e fevereiro de 2008, pela qual expresso meus agradecimentos. 
Corriam os anos setecentos e nos sertões da América portuguesa, depois de se encontrar ouro em grande quantidade, homens e mulheres de todas as "qualidades" (branco, índio, negro, preto, crioulo, mulato, pardo, cabra, mestiço, mameluco, curiboca, caboclo, etc...) e "condições" (livre, escravo, liberto), provenientes de várias partes do império português e de fora dele, concentravam-se em vilas, arraiais e áreas rurais na extensa região que passou a se chamar as Minas Gerais. Junto com a economia pujante, formou-se uma sociedade marcada profundamente pela miscigenação biológica e cultural, na qual a religião e a religiosidade tornaram-se elementos fundamentais de integração social, de organização grupal e familiar e, ainda, de identificação e de distinção entre os habitantes. ${ }^{3}$ Catolicismo, religiões africanas, crenças indígenas, judaísmo e, até mesmo, islamismo foram professados nas Minas Gerais, uns abertamente e outros sob muita camuflagem. Credos e práticas se mesclaram e/ou se superpuseram naquele universo escravista colonial. Entretanto, houve práticas católicas que se universalizaram, abarcando todos ou quase todos os habitantes, independentemente de origem e de fé, em absoluta consonância com os interesses e necessidades do Estado. Registros de batismos, de casamentos e de óbitos eram alguns dos documentos produzidos pelos párocos. Além desses, os testamentos, fortemente marcados pela dimensão religiosa e católica, foram instrumentos indispensáveis tanto para os legados pios e para os preceitos católicos, quanto para os legados materiais, para os arrolamentos de bens, para as declarações mundanas e para a construção de memórias que por meio deles deveriam ser preservadas, ainda que parcialmente e de forma modelar. Os ex-escravos e os não-brancos nascidos livres, muito numerosos nas Minas Gerais, também deixaram seus testamentos, dentre os quais os das mulheres constituíram a maioria. É principalmente esse tipo de documento e esse tipo de relato que se explorará aqui. Declarações como as deixadas pela preta forra Thiadozia de Crastos, parcialmente reproduzidas a seguir, são verdadeiros guias do diálogo historiográfico mantido aqui com os moradores das Minas Gerais do século do ouro e atestam toda a mobili-

2 Martins S. J., Mário: Introdução histórica à vidência do tempo e da mort, Livraria Cruz, Braga, 1969, vol. I, pág. 176.

3 Sobre esses aspectos ver Paiva, Eduardo França \& Ivo, Isnara Pereira (orgs.): Escravidão, Mestiçagem e Histórias Comparadas, Annablume/PPGH-UFMG,. São Paulo/Belo Horizonte, 2008. 
dade e miscibilidade vivenciadas por eles, assim como informam sobre as dinâmicas social, econômica e política aí engendradas.

Em nome da santíssima Trindade Padre e filho Espírito Santo três pessoas e um só Deus verdadeiro. Saibam quantos este instrumento virem que no ano do Nascimento de nosso Senhor Jesus Cristo de mil setecentos e quarenta e oito anos aos três dias do mês de Fevereiro do dito ano eu Thiadozia de Crastos preta forra estando em meu perfeito juízo e entendimento que nosso Senhor me deu de saúde e temendo-me da morte e desejando pôr a minha alma no caminho da Salvação por não saber o que nosso Senhor de mim quer fazer e quando será servido de me levar para si faço este meu testamento na forma seguinte Primeiramente encomendo a minha alma à Santíssima trindade que a criou e rogo ao Padre eterno pela morte e Paixão de seu Unigênito filho a queira receber como recebeu a sua estando para morrer na Árvore da Vera Cruz. e a meu Senhor Jesus cristo peço por suas divinas chagas que já que nesta vida me fez mercê de dar seu precioso sangue e merecimentos de seus trabalhos me faça também mercê na vida que esperamos dar o prêmio deles que é a glória Peço e rogo à gloriosa Virgem Maria nossa senhora Madre de Deus e a todos os Santos da Corte Celestial particularmente ao meu Anjo da guarda e à gloriosa Santa Thiadoza Santa do meu nome e à gloriosa (sic) São Gonçalo, e ao glorioso São Benedito a quem tenho devoção queiram por mim interceder e rogar a meu Senhor Jesus Cristo agora e quando minha alma deste meu corpo sair porque como verdadeira cristã protesto de viver e morrer em a Santa Fé católica e crer o que tem e crê a Santa Madre Igreja de Roma e nesta fé espero de salvar a minha alma não por meus merecimentos, mas pelos da Santíssima Paixão do Unigênito Filho de Deus [...] Meu corpo será sepultado na Capela de nossa Senhora da Lapa filial desta matriz do Sabará em hábito de São Francisco e será levado à sepultura com três clérigos e todos me dirão missa de corpo presente por minha alma e se no dia do meu falecimento se não achar mais que o Capelão da dita capela este me dará a sepultura e se pagarão todos os direitos paroquiais ao meu reverendo vigário como é costume. [...] Declaro que meus testamenteiros mandarão dizer por minha alma sessenta missas de esmola de meia oitava cada uma e assim mais mandarão dizer trinta missas pelas almas do purgatório da mesma esmola e assim mais deixo de esmola a Nossa Senhora da Lapa vinte oitavas de ouro e o menino Jesus cinco oitavas de ouro ...." ${ }^{4}$

Em geral, este é o discurso encontrado na abertura da maior parte dos testamentos setecentistas mineiros, sejam eles de homens ou mulheres, de brancos, negros ou mestiços, de livres, libertos ou descendentes destes últimos. O trecho transcrito acima, por exemplo, foi retirado do testamento de Thiadozia de Crastos, preta forra, natural de Angola, moradora no Arraial de Nossa Senhora da Lapa, termo da Vila de Nossa Senhora da Conceição de Sabará, datado de 1748. O discurso é fruto, certamente, de instruções

4 Archivo Publico Mineiro, Câmara Municipal de Sabará, Belo Horizonte, Minas Gerais (APM/CMS) códice 20, ff. 21v-23. Testamento de Thiadozia de Crastos - Arraial de Nossa Senhora da Lapa, 03 FEV 1748. 
regimentais, produzidas pela administração colonial ou vindas de Portugal, assim como ocorria com os inventários post-mortem ${ }^{5}$, ainda que, às vezes, se encontrem algumas variações.

Os testamentos são um dos tipos mais complexos de registros históricos disponíveis nos arquivos brasileiros. São relatos individuais que, não raro, expressam modos de viver coletivos e informam sobre o comportamento, quando não de uma sociedade, pelo menos de grupos sociais. Nesses documentos, são encontrados elementos definidores do mundo material, bem como da esfera mental da vida colonial.

Dois foram os tipos de testamento conhecidos neste período e ambos eram feitos sob mediação do oficial público. Tratam-se dos

nuncupativos, feitos in extremis, de viva voz ou escritos pelo próprio punho do testador, com a presença de testemunhas e do tabelião público, e os místicos e ológrafos, inteiramente escritos, datados e assinados pelo punho do testador ou a seu rogo, cerrados e lacrados, devendo só serem abertos depois da morte do testador. ${ }^{6}$

O relato testamental é um documento privilegiado para que aflorem os símbolos, cuja função, como esclarecem Berger e Luckmann, "não é apenas instituir uma classificação, mas também introduzir valores, modelando os comportamentos individuais e coletivos e indicando as possibilidades de êxito dos seus empreendimentos". ${ }^{7}$ É importante ressaltar então que se um

5 Embora não seja conhecida a regulamentação seguida pelos escrivães para elaborarem os testamentos setecentistas, ela certamente existiu, mesmo que manuscrita, como no caso dos inventários post-mortem. Sobre o livro que estipula as normas para a elaboração desses últimos documentos (existe um exemplar no arquivo do Museu do Ouro, em Sabará) ver Paiva, Eduardo França: "Os inventários mineiros: fontes para a história colonial”, Caderno de Filosofia e Ciências Humanas. FINP, Belo Horizonte, 1993, n. 1, pags. 26-29.

6 Marcílio, Maria Luíza: "A morte de nossos ancestrais" en Martins, José de Souza (org.): A morte e os mortos na sociedade brasileira, Hucitec, São Paulo, 1983, pág. 68. A autora traz explicações sobre os tipos de testamentos, se nuncupativos, feitos in extremis, de viva voz ou se místicos ou ológrafos e sobre como eles eram escritos. Considerações mais detalhadas sobre o tema são apresentadas em Oliveira, Maria Inês Côrtes de: O liberto: o seu mundo e os outros; Salvador, 1790/1890, Corrupio/CNPq, São Paulo, 1988, pág. 6, onde se pode ler: "O testamento público era lavrado por tabelião, em livro próprio, na presença de cinco testemunhas; o testamento cerrado ou místico era redigido em carta sigilosa, pelo testador ou alguém de sua confiança, autenticado e lacrado pelo tabelião perante cinco testemunhas e registrada nota de aprovação em livro notarail; o testamento ológrafo ou particular podia ser escrito pelo testador ou a seu pedido, diante de cinco testemunhas que deviam tomar conhecimento de seu conteúdo e assiná-lo; o testamento oral ou nuncupativo, realizado perante seis testemunhas; o testamento de mão-comum, feito por marido e mulher, com instituição recíproca, era reconhecido só pelo costume.

7 Berger, P. L. \& Luckmann, T.: The social construction of reality: a treatise in the Sociology of knowledge,.Doubleday, New York, 1966 citados por Baczko, Bronislaw: "Imaginação Social”, en Enciclopédia Einaudi. (trad. port.) vol. 5, Imprensa Nacional/Casa da Moeda, Lisboa, 1986, págs. 296332, pág..311. 
símbolo não consegue fixar-se, nem modelar os comportamentos humanos é, sobretudo, por conta de uma certa autonomia daquilo que Bronislaw Baczko chama de comunidade de imaginação. ${ }^{8}$ Em última análise, é esta comunidade que aceita ou não incorporar os símbolos, determinando a construção de imagens, a conformação das estruturas mentais e influenciando a dinâmica das relações sociais. Os símbolos são elementos que compõem os hábitos e os costumes do dia-a-dia e as atitudes em torno de festas, cultos, cerimônias, visitas e viagens, diante do nascimento e da morte. E é esta última expressão da vida que dá sentido ao registro testamental. Muitos testadores registraram suas últimas vontades quando pressentiram o fim, num momento em que a agonia do corpo e do espírito provocava alterações em seus sentimentos e em seu modo de viver.

Walter Benjamin conseguiu captar nos períodos de agonia algumas das transformações comuns aos moribundos. Num de seus textos, onde o objeto de análise é o narrador, ele comenta:

Ora, é no momento da morte que o saber e a sabedoria do homem e sobretudo sua exis-
tência vivida - e é dessa substância que são feitas as histórias - assumem pela primeira
vez uma forma transmissível. Assim como no interior do agonizante desfilam inúme-
ras imagens - visões de si mesmo, nas quais ele se havia encontrado sem se dar conta
disso -, assim o inesquecível aflora de repente em seus gestos e olhares, conferindo a
tudo o que lhe diz respeito aquela autoridade que mesmo um pobre-diabo possui ao
morrer, para os vivos em seu redor. Na origem da narrativa está essa autoridade. ${ }^{9}$

A agonia é para o doente o espaço da derradeira narrativa, que assume imediatamente, com exceção dos delírios, a condição de verídica junto às pessoas que o rodeiam. Mais do que isso, é o momento de revelar segredos guardados por vários anos, espaço reservado às confissões, à prática dos mais nobres sentimentos cristãos e à tentativa de um acerto de contas espiritual, visando a absolvição divina.

Os testamentos setecentistas funcionaram como canais para a expressão destas atitudes por parte dos habitantes das Minas e do restante da América portuguesa. Em todas as aberturas, por exemplo, fossem elas mais ou menos rebuscadas ou completas, o discurso e os próprios testadores buscavam o mesmo objetivo: a salvação da alma, após a morte. Na verdade essa era uma preocupação que acompanhava, durante toda a vida, a maio-

8 Baczko, Bronislaw: “Imaginação ...”, pág. 325.

9 Benjamin, Walter: "O narrador; considerações sobre a obra de Nikolai Leskov." in Obras escolhidas; magia e técnica, arte e política, Brasiliense, São Paulo, 1987. 
ria das pessoas daquela época. Por isso mesmo, diante da iminência da morte, os testamentos surgiram como o principal instrumento para que cada moribundo pudesse ali imprimir um perfil de bom cristão e, portanto, de merecedor da salvação eterna. Assim, o testador impunha aos que o rodeavam em sua agonia e legava ao futuro uma auto-imagem virtuosa. Talvez, intimamente, tentasse convencer-se de que na hora do julgamento pesariam mais as suas boas ações e suas qualidades e menos os delitos e pecados cometidos. Para tanto, precisaria contar com as súplicas de parentes e amigos que permaneciam vivos e a intercessão dos santos e santas que formavam a corte celeste; eles rogariam a Deus, piedosa e incessantemente, pela salvação da alma daquele devoto ou devota. Os testamentos serviam, também, para isso. Talvez, principalmente para isso. Eram exercícios de piedade dos testadores e serviam, também, para suscitar esse sentimento entre os que aguardavam a morte, pois esses últimos sabiam que ao suplicarem pela alma alheia estariam angariando futuras súplicas e facilitando a salvação da própria alma.

Mas, para o historiador, a posteriori, os testamentos têm outra serventia. ${ }^{10}$ Eles se transformaram em uma das mais ricas vias de ligação com o

10 A investigação sistemática de testamentos e inventários post-mortem como fontes historiográficas no Brasil foi pioneiramente realizada por Machado, Alcântara: Vida e morte do bandeirant, Itatiaia/EdUSP, Belo Horizonte/São Paulo, 1980, livro publicado pela primeira vez em 1929. Em 1933, Freyre, Gilberto: Casa Grande \& Senzala; formação da família brasileira sob o regime da economia patriarcal, $27^{\mathrm{a}}$ ed. Record, Rio de Janeiro, 1990, lança mão desses tipos de documentos, mas não com o mesmo ímpeto de Machado. A partir da década de 70, sob a influência da pesquisa histórica francesa, começaram a ser produzidos estudos que recorreram a essas fontes: ver, por exemplo, Mattoso, Kátia M. de Queirós: Testamentos de escravos libertos na Bahia do século XIX; uma fonte para o estudo de mentalidades. Centro de Estudos Baianos/UFB, Salvador:, 1979. Na década seguinte, foram produzidos, entre outros, os estudos de Silva, Maria Beatriz Nizza da: Sistema de casamento no Brasil colonial, T. A. Queirós/EdUSP, São Paulo, 1984, Magalhães, Beatriz Ricardina de: La société ouroprétaine selon les inventaires post-mortem (1740-1770). Tese de Doutorado apresentada à Universidade de Paris, 1986 e Oliveira, Maria Inês Cortes de: O liberto ...., 1988. Para os anos mais recentes ver, Reis, João José: A morte é uma festa; ritos fúnebres e revolta popular no Brasil do século XIX, Companhia das Letras, São Paulo, 1991; Priore, Mary del: Ao sul do corpo; condição feminina, maternidades $e$ mentalidades no Brasil Colônia, .José Olympio/EdUnB,. Rio de Janeiro/Brasília, 1993; Paiva, Eduardo França: Escravos e libertos nas Minas Gerais do século XVIII; estratégias de resistência através dos testamentos. Annablume, São Paulo, 1995; Paiva, Eduardo França: Escravidão e universo cultural na Colônia; Minas Gerais - 1716-1780. EdUFMG, Belo Horizonte, 2002. Entre os estudos franceses, que, desde o início da década de 70, têm escolhido testamentos e inventários post-mortem como suas fontes básicas devem ser lembrados Ariès, Philippe: Essais sur l'histoire de la mort en Occident du Moyen Age à nos jour, Éditions du Seuil, Paris, 1975; Ariès, Philippe: L'homme devant la mort, Éditions du Seuil, Paris, 1977; Vovelle, Michel: Mourir autrefois; attitudes collectives devant la mort aux XVIIe siècle, Gallimar/Julliar, Paris, 1974; Vovelle, Michel: Piété barroque et déchristianisation en Provence au XVIIIe siècle, Éditions du Seuil, Paris, 1978 (publicado pela primeira vez em 1973) e Vovelle, Michel: La mort et l'Occident de 1300 à nos jours, Gallimar, Paris, 1983. 
passado colonial, revelando práticas, idéias, demandas, tradições, costumes, expectativas, representações, desejos e receios expressos por homens e mulheres setecentistas (brancos, negros e mestiços, livres e libertos), legítimos testemunhos de um tempo já bastante afastado de nós e de um espaço que eles também construíram. Aí reside um importante aspecto desses documentos: a preservação de porções esclarecedoras daquele universo cultural, de seus aspectos materiais, imaginários e políticos, muitas vezes relatados pelos próprios testadores, mesmo que registrados por escrivães. Bom para a moderna historiografia Social e Cultural. A partir dessas impressões deixadas em papel e enriquecidas pelas informações mais frias e objetivas contidas nos inventários post-mortem é possível infiltrar-se, mais profundamente, no universo colonial brasileiro. Pode-se estudar desde as permanências inscritas num tempo longo, até representações que viriam a sofrer, mais tarde, profundas transformações, como, por exemplo, as representações do céu, do inferno e do purgatório, passando pela indumentária, pela lingüística, pelas relações de sociabilidade e pelas estratégias de dominação e de resistência. ${ }^{11}$ A conturbada e multifacetada sociedade mineira pode ser observada, ainda que sempre parcialmente, através desses documentos. Eram aí registrados os mais corriqueiros aspectos das relações mantidas entre escravos, libertos e livres, assim como o jogo que eles estabeleceram com o mundo extraterreno, visando a salvação de suas almas.

É importante sublinhar aqui algumas especificidades dos testamentos produzidos no período e nas áreas coloniais. Esses documentos, no geral, e, particularmente, os relativos aos homens e mulheres forros, ao evocarem a todo o momento aquele ambiente colonial escravista e fortemente mestiçado, constroem uma diferença essencial se comparados aos similares europeus, que, muito mais raramente, possuíam essas mesmas características. $\mathrm{O}$ fato de testarem ex-escravos (de origens africanas, crioulos e mestiços), já é, em si, elemento que os distingue e aumenta ainda mais sua importância histórica, pelo menos para os que se debruçam sobre a histó-

11 Sobre a potencialidade informativa dos testamentos e inventários post-mortem coloniais, ver: Mattoso, Kátia M. de Queirós: Testamentos ...; Paiva, Eduardo França: "Os inventários ... “; Paiva, Eduardo França: "Discussão sobre fontes de pesquisa histórica: os testamentos coloniais", LPH - Revista de História, Mariana, 1994, n. 4, págs. 92-106,; Paiva, Eduardo França: Escravos ...; Paiva, Eduardo França: "Testamentos, universo cultural e salvação das almas nas Minas Gerais do século XVIII", Revista do IFAC. Ouro Preto, n. 2, págs. 84-91, e Paiva, Eduardo França: Escravidão ... 
ria da América. A coleção brasileira de testamentos de forros e de seus descendentes de primeira geração é, muito provavelmente, a maior existente, pois conjugam-se, para tanto, dois fatores essenciais: a enorme quantidade de alforrias existentes desde o século XVII até o fim da escravidão, em 1888 (o período colonial no Brasil se estende até 1815, quando se cria o reino do Brasil, agregado ao de Portugal e do Algarve) e o forte catolicismo praticado generalizadamente pela população, por vezes de maneira sincrética, o que, aqui, pouco importa. No geral, esses documentos, sejam os de ex-escravos, sejam os de livres de toda "qualidade", deixaram muitas informações preciosas sobre a mobilidade física e social que marcou indelevelmente o Brasil escravista, atestando das mais variadas maneiras a fragilidade das fronteiras sociais que distinguiam livres e escravos; brancos, índios, negros, crioulos e mestiços; ricos e pobres; naturais e estrangeiros ou católicos, não católicos e os que misturavam as tradições. Talvez, a melhor expressão dessa diversidade e da forma de distiguir os agentes que a constituíam, o que não significou, em absoluto, um "engessamento" dela, tenha sido o emprego comum das categorias "qualidade"12 e "condição". ${ }^{13}$ Membros de uma e outra categorias transitaram pelas estradas e, principalmente, pelas ruas e vielas da urbi colonial, bem como pelas várias dimensões de distinção social e cultural daquela sociedade, deixando relatos esclarecedores sobre essa dinâmica em seus testamentos e inventários post mortem, como se verá mais à frente.

Mas, voltemos à descrição dos testamentos, para que se compreenda melhor a complexidade desse registro. $\mathrm{O}$ esforço de convencimento que se iniciara na abertura do texto continuaria pelas outras partes dele. Após os rogos aos anjos e santos pela acolhida das almas no paraíso celestial, chegava a hora de começar a reconhecer os pecados cometidos. Era, também, o momento de demonstrar arrependimento, essa mistura de sentimento e prática incentivada pelo catolicismo, que garantia o povoamento do céu,

12 Os brancos eram às vezes, identificados pelo uso dos titulos D. e Dona e, outras vezes, pelo simple fato de não se aportar qualquer elemento identificador antes ou à frente de seus nomes.

13 Além de livres, escravos e forros, havia os coartados, uma condição especial assumida por alguns escravos em processo de libertação, embora essa categoria estivesse lastreada em direitos costumeiros e não constasse do corpus jurídico até, pelo menos, a segunda metade do século XVIII. Designava-se como coartado ou quartado, como era comum aparecer nos documentos, os escravos envolvidos em processos de coartação ou quartação. As coartações eram os processos de pagamento parcelado das alforrias, fruto da negociação direta entre escravos e proprietários, que se estendiam por 3 ou 4 anos, com prestações semestrais ou anuais. Ver sobre o tema Paiva, Eduardo França:. Escravos ... e Paiva, Eduardo França: Escravidão .... 
ainda que precedido de um estágio de remissão cumprido no purgatório, e evitava a formação de uma superpopulação no inferno. ${ }^{14}$ Melhor hora para declarar-se arrependido não poderia haver, como escreveu Walter Benjamin, em trecho transcrito acima. E, como afirma Marco Antonio Silveira, ao discutir "o papel fundamental desempenhado pela palavra na sociedade mineira (...) jurar em falso e negar uma dívida real poderia implicar em dificuldades para a salvação da alma." Para o autor, muito além da suposta eficácia do juramento sobre os Evangelhos, norma prevista nas Ordenações Filipinas e que dava um peso muito grande à palavra do declarante, em Minas ela circulava "cotidianamente como moeda de mercado" (base da garantia de pagamento de dívidas corriqueiras) e o costume encontrava-se enraizado no imaginário da população. ${ }^{15}$ Os moradores das Minas realmente incorporaram o costume, malgrado a existência continuada de mentiras e omissões. $O$ peso da palavra emitida ficava bem claro quando cada um deparava-se com a iminência da morte e, imediatamente, providenciava a feitura do testamento.

A mentira era associada ao procedimento típico dos condenados ao inferno. Mas a mentira do agonizante transformava-se em verdade potencial para aqueles que ao redor de um moribundo acompanhavam seus últimos suspiros. Não obstante, a Deus todo poderoso, onipotente e onipresente, nada escapava e, portanto, era melhor arrepender-se das faltas e suplicar o perdão divino, que inventar verdades para serem incorporadas pelo mundo dos vivos. O medo da condenação da alma ao interminável suplício satânico, imagem dantesca que fazia parte do dia-a-dia daquelas pessoas tão

14 Pelo menos individualmente, os testadores mineiros não pareciam acreditar em qualquer possibilidade de suas almas irem para o inferno. Todos reconheciam ser pecadores, mas demonstravam merecer a salvação, ainda que passando pelo purgatório, sem, no entanto, explicitar essa última alternativa. Geralmente, a expressavam dizendo estarem doentes, temerosos da morte e "desejando por minha alma no caminho da salvação, por não saber a que Deus Nosso Senhor de mim quer fazer e quando será servido de me levar para si ...". Trata-se de uma frase empregada quase mecanicamente pelos escrivães, mas usual e muito sugestiva. A partir de seu uso e da crença nela, fica difícil acreditar que os fiéis, nas Minas, aceitassem a velha idéia, tão divulgada entre os católicos na Europa, de que muitos seriam chamados, mas poucos seriam eleitos por Deus. Ver sobre esse assunto Delumeau, Jean: La péché et la peur; la culpabilisation en Occident (XIIIe-XVIIIe siècles), Fayard, Paris, 1983, págs. 315-338.

15 Ver Silveira, Marco Antônio: O universo do indistinto; Estado e sociedade nas Minas setecentistas (1735-1808), Hucitec, São Paulo, 1997, pág. 103. É preciso, contudo, salientar certa inversão de valores agregados a alguns termos corriqueiros, tais como o sim e o não. Isso foi usual e fez parte dos ajustes cotidianos realizados pela população da Colônia. $\mathrm{O}$ empenho da palavra de maneira rígida, como aponta Silveira e a inversão de alguns significados agregados a alguns termos ocorreram simultaneamente. 
intimamente ligadas ao visual, ${ }^{16}$ arrastava a maioria dos testadores para a primeira opção. O peso da palavra para os mineiros tornava-se mais acentuado diante das "verdades" pintadas e esculpidas, portanto, imaginadas e, sobretudo, vistas a toda hora, durante dia e noite, naquele enorme cenário barroco das Gerais. Imaginar e visualizar o pecado e a salvação, através dos sermões, das missas, das leituras (individuais, coletivas e dos comentários sobre elas) e da iconografia eram práticas comuns nas terras brasileiras desde os primórdios da colonização. Haja vista os juízos demonizadores do lugar, emitidos pelo Padre Manoel da Nóbrega, no século XVI e por Frei Vicente do Salvador, no século XVII. A Igreja partia do pecado para ver a América portuguesa, mas houve os que a tomaram como paraíso. Deste embate ou, talvez, desta mistura, parece ter emergido uma terceira descrição, que vigoraria durante bastante tempo e chegaria forte ao século XVIII mineiro: o purgatório. Nesse caso, o paraíso celeste podia ser vislumbrado da Colônia. A seus habitantes estavam franqueados os prazeres mundanos e o apego à vida, claro, sem os excessos que poderiam reverter a situação confortável e condená-los à perdição. ${ }^{17}$

Era, então, muito importante lembrar-se do pecado naquela sociedade de expiadores e, evidentemente, livrar-se dele. Outra vez, a palavra aparecia supervalorizada entre os testadores, pois era ela que atestava a sinceridade e a veracidade do reconhecimento das culpas, do arrependimento declarado e da súplica pelo perdão. Às vezes, a preocupação dos testadores chegava ao extremo de fazê-los recear não terem pedido perdão por alguma falta já esquecida e, por isso, complicarem-se no julgamento divino.

16 Ver, sobre esse assunto, Ávila, Affonso: $O$ lúdico e as projeções do mundo barroco, Perspectiva, São Paulo, 1971, págs. 197-233. Segundo o autor, "um aspecto comum a todas as manifestações do barroco nas Minas do século XVIII, seja na área da criação artística ou na órbita mais ampla do estilo de vida, é a preocupação do visual, a busca deliberada da sugestão ótica, a necessidade programática de suscitar, a partir do absoluto enlevo dos olhos, o embevecimento arrebatador e total dos sentidos". Ver, também, Paiva, Eduardo França: História \& Imagens, Autêntica, Belo Horizonte, 2002.

17 Sobre o desenvolvimento da idéia de pecado no Occidente, ver Delumeau, Jean: La péché .... Sobre o pecado no Brasil Colônia, ver Souza, Laura de Mello e: O diabo e a Terra de Santa Cruz; feitiçaria e religiosidade popular no Brasil colônia, Companhia das Letras, São Paulo, 1986 e Vainfas, Ronaldo: Trópico dos pecados; moral, sexualidade e inquisição no Brasil, Campus, Rio de Janeiro, 1989. Sobre as idéias de paraíso terrenal, ver o clássico Holanda, Sérgio Buarque de: Visão do Paraíso; os motivos edênicos no descobrimento e colonização do Brasil, Companhia Editora Nacional/EdUSP, São Paulo, 2 ed. 1969 (editado pela primeira vez em 1959). Sobre a inclusão do Purgatório entre os Novíssimos do Homem (Morte, Juízo, Inferno e Paraíso) e sobre sua apropriação nas Minas Gerais setecentistas, ver Campos, Adalgisa Arantes: A terceira devoção do Setecentos mineiro: o culto a São Miguel e Almas. Tese de Doutorado apresentada à Universidade de São Paulo, 1994. 
Mariana Gomes Ribeira, natural da capitania do Rio de Janeiro, já viúva e sem filhos vivos, moradora na vila de São José Del Rei, em 1739, parecia não ter dúvidas sobre a salvação de sua alma, mas, em todo caso, procurava resguardar-se. Ela declarava deixar "aos Santos Lugares de Jerusalém seis oitavas para descarga de minha consciência por alguma coisa que poderei mal levado ou engano em contas de quem não lembro ..." e continuava à frente: "Declaro que por algumas vezes que tenho prometido missas a alguns Santos ou Santas que me não lembro para o que deixo cinqüenta oitavas para se dizerem pelas tenções que prometi e por modo de sufrágio pelas Almas." ${ }^{18}$ Morrer devendo seus prováveis intercessores junto a Deus não parecia, para Mariana, ser uma boa estratégia. Tratou, então, de saldar suas dívidas, mesmo que isso viesse a ocorrer após o seu falecimento; valia a intenção!

No imaginário mineiro setecentista, logo após a morte do corpo, a alma começava a acertar as contas relativas aos pensamentos cultivados e aos atos realizados durante a sua permanência na terra, aprisionada a um corpo humano. Quando as faltas cometidas envolviam dinheiro e bens materiais, parece ter sido mais fácil reverter o quadro desfavorável. Muitos tentaram compensar esse tipo de procedimento condenável com legados pios e materiais nos testamentos. Afinal de contas, a intenção era construir uma imagem de "pecador convertido" e não de um pecador inveterado. Aliás, a idéia de "pecador convertido" calhava bem com a de um ser humano naturalmente susceptível ao pecado e de uma outra, que tornava o arrependimento uma atitude comum entre os homens, posto que a maioria deles desejava colocar sua alma na eterna proteção divina. O termo, que uso aqui entre aspas, é homônimo ao título dado a um livro bastante difundido entre a população setecentista mineira. As leituras deste texto e de outros livros ou relatos feitos a partir delas devem ter influenciado as atitudes daquelas pessoas diante da vida e, principalmente, da morte. ${ }^{19}$

18 Museu Regional de São João Del Rei/Inventários - São João Del Rei, Minas Gerais (MR/INV),- caixa 212. Inventário post-mortem de Mariana Gomes Ribeira - São José Del Rei, 02 JAN 1740 .

19 O título da referida obra é "O Pecador Convertido" e ela aparece arrolada em um significativo número de inventários post-mortem de pessoas que tinham livros. Sobre as apropriações de leituras feitas por letrados e não letrados ver, entre outras, as discussões propostas em Acervo: Revista do Arquivo Nacional, Rio de Janeiro, 1995, n. 01/02; Chartier, Roger: A História Cultural entre práticas e representações. (trad. port.), Difel, Lisboa, 1990; Chartier, Roger: A ordem dos livros; leitores, autores e bibliotecas na Europa entre os séculos XVI e XVIII. (trad.), EdUnB, Brasília, 1994; Darnton, Robert: $O$ grande massacre de gatos e outros episódios da história cultural francesa. (trad.), Graal, Rio 
Esse ambiente barroco ${ }^{20}$ que emerge dos testamentos extrapolava estilos artístico-literários. Ele atingia, na verdade, o universo cultural dos mineiros, em suas práticas mais corriqueiras, embora não o fizesse de forma absoluta e irredutível. Era uma visão de mundo e um conjunto comportamental construídos a partir daquela realidade histórica setecentista, escravista, notavelmente urbana e mercantil, culturalmente marcada ora pela mescla, ora pelo impermeável. Parece-me que ninguém escapava dele: brancos, negros e mestiços; livres, libertos e escravos; homens e mulheres; adultos e crianças, embora, claro, apropriavam-se diversamente dele. Esse movimento dependia das épocas, das regiões e dos interesses perseguidos por cada agrupamento social. Neste sentido, os testamentos constituem-se em riquíssimas fontes para o estudo do tema. E tornam-se ainda mais ricos quando os textos explicitam vieses de comportamento - formalizando-os ou distinguindo-os - e mesmo quando tentam camuflar atitudes desviantes do modelo de vida virtuosa, imposto de cima para baixo. Nesses documentos ficaram registradas, por certo, as impressões e as preocupações daquela gente setecentista diante do embate travado, todos os dias, entre os prazeres mundanos que saciavam o corpo e a necessidade de negá-los para que a alma, pura, merecesse ser acolhida por Deus. Os homens e as mulheres desse tempo parecem ter conseguido transitar entre um campo e outro, não sem culpabilizarem-se e procurarem arrepender-se em algumas ocasiões,

de Janeiro, 1986; Darnton, Robert: Boêmia literária e Revolução. (trad.), Companhia das Letras, São Paulo, 1987; Darnton, Robert: O beijo de Lamourette; mídia, cultura e revolução. (trad.), Companhia das Letras, São Paulo, 1990; Darnton, Robert: Edição e sedição: o universo da literatura clandestina no século XVIII. (trad.), Companhia das Letras, São Paulo, 1992; Villalta, Luiz Carlos: "Os clérigos e os livros nas Minas Gerais na Segunda metade do século XVIII", Acervo: Revista do Arquivo Nacional. Rio de Janeiro, 1995, n. 01/02 pags. 19-52, e Villalta, Luiz Carlos: "O que se fala e o que se lê: língua, instrução e leitura” in Novais, F. \& Souza, L. de M. e (orgs.): História da Vida Privada no Brasil - Cotidiano e vida privada na América portuguesa, Copanhia das Letras,. São Paulo, 1997, págs. 331-385.

20 O que chamo aqui de ambiente barroco está muito próximo da definição dada por Affonso Ávila. Este autor entende o barroco nas Minas, "não enquanto tão-só um estilo artístico, mas sim como fenômeno de maior complexidade - um estado de espírito, uma visão de mundo, um estilo de vida, de que as manifestações da arte serão a expressão sublimada.” Ver Ávila, Affonso: Resíduos ... pág. 10. E mais: "Esses três elementos [o lúdico, a ênfase visual e o persuasório], convergindo na feição característica do estilo artístico, evidenciada tanto no exemplo singular dos grandes arquétipos como na generalidade do repertório menor, acabariam mudando não só as regras do modo de formar o artista, porém mais significativamente as regras do ver e do sentir do próprio homem do período. O Barroco já não representará então apenas um estilo artístico, mas uma sistematização de gosto que se reflete em todo um estilo de vida, um estilo portanto global de cultura e de época para cuja síntese o lúdico poderá, sem o risco da especiosidade, ser tomado como categoria crítica." Ibidem, pág. 22. Ainda assim, é preciso sublinhar, não entendo o Barroco como a "obra de arte total", isto é, o gesamtkunstwerk, englobadora e sintetizadora das manifestações culturais setecentistas das Minas. 
nem sem, em outras ocasiões, sentirem-se puros, vitoriosos sobre as tentações, merecedores, portanto, da salvação eterna.

$\mathrm{O}$ atormentado testador, imbuído de uma visão barroca de mundo, tentava, através de vários artifícios, salvar sua alma, demonstrando que, muitas vezes, ela discordara das atitudes reprováveis praticadas pelo corpo. ${ }^{21}$ Neste momento, o todo era desmembrado, como se as partes pudessem ser responsabilizadas por sua autonomia comportamental. Passa-se, então, a mais rogos pela sorte dela, já que o destino dele é apodrecer e retornar ao pó de onde originara-se. Talvez, por isso, noutras vezes, o corpo aparece como o dominante e a alma como submissa, o que poderia vir a pesar positivamente no julgamento dela. Embora de maneira menos incisiva e dramática, o jogo observado nos testamentos assemelha-se aos diálogos imaginários travados entre o corpo e a alma, comuns na literatura e no gosto popular europeus, desde a Idade Média. Já em Minas Gerais, não parecem ter sido muito cultivados ou, talvez, não fossem muito conhecidos. Pelo menos entre os testadores setecentistas mineiros, para compensar as fraquezas da alma eram encomendadas dezenas, centenas e até milhares de missas por sua intenção. Antes das celebrações, porém, o ritual iniciava-se com cortejo público, acompanhado por párocos e irmandades, familiares, amigos e gente humilde arregimentada às pressas e, às vezes, paga para participar do evento, todos rezando pelo bom encaminhamento da alma saída daquele corpo sem vida. Além disso, antes do enterro, eram comuns as missas de corpo presente e para que tudo ocorresse da forma desejada pelo fiel, todos os gastos relacionados ao evento eram previstos no testamento, ficando os testamenteiros responsáveis por sua perfeita execução. Essa liturgia da morte cristã incluía itens que, geralmente, eram encontrados em todos os casos, como, por exemplo, o tipo de mortalha a ser utilizada; a cera a ser distribuída entre os acompanhantes do cortejo; as missas por diversas intenções; as irmandades que acompanhariam o féretro; o local do enterro e, até mesmo, o pagamento de anuais atrasados, devidos às irmandades às quais o testador era filiado. Quanto mais rico fosse o testador, maior era a pompa fúnebre planejada por ele, salvo raras exceções.

De uma maneira geral, o ritual que se desenrolava desde a morte até o enterro do corpo, englobando as missas póstumas, era compartilhado pela maioria da população livre e liberta das Minas. É provável que entre os

21 Sobre o barroco e o corpo humano, ver Camporesi, Piero: La chair impasible, Flammarion, Paris, 1986. 
escravos, sobretudo entre os nascidos no Brasil, vários tenham adotado procedimento semelhante ou tenham recebido tratamento similar por parte de seus proprietários. Mesmo sendo raros os registros esclarecedores sobre essa situação, sobretudo os produzidos em Minas Gerais, no século XVIII, pode-se intuir que a apropriação das atitudes católicas e oficiais diante da morte, tão bem demonstrada pelos testadores libertos, tenha se iniciado no cativeiro. Lá, também, iniciara-se a incorporação de outros tantos valores dominantes. Todos os libertos, cujos testamentos investiguei, adotaram, com maior ou menor fidelidade, os itens que compunham o rito fúnebre católico. Assim, por exemplo, a preta forra, Simoada Costa Dias, natural da Ilha de São Tomé e moradora na vila Nova da Rainha, em 1739, exigia que seu corpo fosse amortalhado no hábito de São Francisco de Assis, acompanhado pela Irmandade das Almas e por "meu Pároco com os sacerdotes que se acharem" e que o mesmo pároco dissesse vinte e cinco missas de corpo presente. ${ }^{22}$ Já a preta forra, Anna Vieyra, Angola, moradora em Sabará, em 1741, queria como mortalha o hábito de São Francisco de Assis ou de Santo Antônio. Seu corpo deveria ser acompanhado pela Irmandade das Santas Almas, pelo reverendo pároco e mais cinco sacerdotes, que diriam missa de corpo presente. Ordenava aos testamenteiros, entre eles o reverendo padre Francisco Coelho de Santa Maria, que após sua morte deveria ser dita uma capela de missas (cinqüenta missas) por sua alma. ${ }^{23}$

Os brancos ricos, é claro, diferenciavam-se do restante da população transformando sua morte em um espetáculo pomposo e rebuscado. Alguns testadores, na verdade uma parcela bem reduzida deles, não obstante, optavam por funerais simples, mesmo possuindo fortunas suficientes para promoverem cortejos mais suntuosos. ${ }^{24}$ Talvez achassem que assim estariam agradando mais a Deus e, por isso, facilitando a entrada no paraíso celeste. Entretanto, havia conceitos diferentes de simplicidade e alguns testadores, embora dissessem não querer pompa alguma no enterro, planejavam féretros ricos em suas declarações e determinações testamentais.

22 Museu do Ouro/Cartório do Primeiro Ofício/Testamentos - Sabará, Minas Gerais (MO/CPO-TEST) - códice 2, ff. 120v-124. Testamento de Simoada Costa Dias - Vila Nova da Rainha, 19 FEV 1739.

23 Ibidem, códice 4, ff. 125v-129v. Testamento de Anna Vieyra - Sabará, 27 SET 1741.

24 Michel Vovelle encontra uma situação bem semelhante, na França do século XVIII. Diz o autor que a elite provençal, mais entre o clero e menos entre os nobres, buscava a simplicidade fúnebre, o que não deixava de ser uma expressão de vaidade e, também, uma forma de diferenciação social, já que a elite podia optar pela simplicidade. Contudo, Vovelle sugere que essa prática estava no meio de uma "révolution de la sensibilité". Ver Vovelle, Michel: Piété ... págs. 94-100. 
O destino das almas era uma das grandes preocupações daquela gente, mas não era a única. Imaginar e, até mesmo, descrever o céu, o inferno e o purgatório, também mereceu a atenção dos mineiros. Descrições dantescas misturavam-se, no imaginário colonial, com tradições orais provenientes de várias partes ou reconstruídas nos trópicos e com visões de mundo miscigenadas e/ou superpostas. O contato envolveu, também, dogmáticas verdades católicas impostas à população, às vezes de maneira autêntica e outras vezes já modificadas, por autoridades religiosas e leigas que atuavam na região. Naquele barroco ambiente mineiro do Setecentos, era importante, era mesmo necessário que o "bom cristão" se preparasse, ininterruptamente, para atingir, com glória, o mais valioso momento da vida humana, isto é, a boa morte..$^{25}$ Os testamentos, então, acabavam por expressar uma espécie de pedagogia do bem morrer, que, na verdade, fazia parte das práticas cotidianas, das representações vivenciadas no dia-a-dia pelos habitantes das Minas, mesmo que, no geral, de maneira pouco sistematizada. Como bem disse o historiador, filósofo e jesuíta português, Mário Martins, referindo-se à destemporalização acalentada pela "filosofia cristã e [pela] teologia” desde a Idade Média até os séculos XVII e XVIII,

Em nós, o tempo apresenta-se como inseparável do movimento e este implica a morte de alguma coisa, ou de algum estado. (...) Entre as duas extremidades vazias [a memória e o ponto de chegada, isto é, a morte, o deixar-de-ser], o presente reduz-se quase a uma abstração, como o ponto geométrico. O passado é o ter-ido-morrendo; o futuro é o estar-chegando-para-a morte; e o presente, de tão grande densidade subjetiva, é o estar-morrendo a cada instante..$^{26}$

Certamente, Martins não pensava nos moradores setecentistas das Gerais quando escreveu essas palavras. Mas, sem medo de incorrer em anacronismo ou transposição inadequada de costumes, devo ressaltar que elas servem bem para se refletir sobre o universo mental dos homens e mulheres mineiros, pelo menos sobre suas reações e atitudes diante da morte iminente. Elas ajudam a melhor pensar sobre o significado dos relatos testamentais e sobre o próprio perfil que cada testador procurava construir nesses documentos, para apresentá-lo aos que o rodeavam na agonia e, depois, na tumba. O perfil, imaginava, servia-lhe, ainda, para impressionar as autoridades celestes e para ser legado ao futuro.

25 Paiva, Eduardo França: Testamentos, universo cultural ....

26 Martins S. J., Mário: Introdução ... vol. I, pág. 18. 
Mas, os testamentos não se limitam aos aspectos até aqui abordados, isto é, às invocações pela salvação da alma, às disposições sobre o enterro do corpo e aos legados espirituais. Estes são os temas que dominam as duas primeiras partes desses documentos. Seguem, contudo, pelo menos três outras partes facilmente identificáveis dos testamentos. Na primeira delas encontram-se o inventário resumido (às vezes completo) dos bens móveis e imóveis; as alforrias, coartações, arrestos e vendas de escravos; as disposições e legados materiais e a identificação de dívidas e créditos. Logo depois vêm as disposições gerais, a assinatura ou sinal do testador, as assinaturas do escrivão e do oficial responsável pelo registro, pela aprovação e pela abertura do testamento. Finalmente, aparecem os codicilos, isto é, as alterações empreendidas pelo testador, após a última versão testamentária. $\mathrm{Na}$ verdade, os codicilos eram raros.

Não obstante a potencialidade informativa das outras partes dos documentos investigados, as duas primeiras foram privilegiadas aqui por trazerem os aspectos mais próximos do universo mental ou do imaginário em vigor naquela região e naquela época. Essas nuanças foram componentes vitais para a formação daquilo que se pode chamar de ambiente barroco das Minas, isto é, como já disse, práticas, representações, projetos de vida, visões de mundo, miscigenadas e/ou superpostas, em constante transformação, embora submetidas a ritmos às vezes lentos, às vezes frenéticos, misturando permanências e descontinuidades, essencialmente atormentadas pelo antagonismo - vivenciado àquela altura - entre o gosto de viver e o medo de pecar, entre as necessárias penitências do corpo e a desejada salvação eterna da alma.

As informações contidas na terceira parte dos testamentos revelam, também, nobres atitudes e sentimentos — benevolência, piedade, estima, gratidão e reconhecimento- que povoavam o espírito dos moribundos de todas as condições e que certamente, para eles, representavam o ingresso no reino de Deus.

Por vezes os primeiros legados materiais destinavam-se às igrejas e às causas religiosas. É claro que as doações variavam conforme as posses e as intenções dos testadores. Muito ricos, foram os legados desse tipo feitos por Izabel Moreira de Castilho, natural da Vila de Taubaté, capitania de São Paulo, moradora em Sabará, em 1756, casada com o Alferes André Francisco Braga, sem que tivessem filhos. Izabel deixava 100.000 réis para o ornato do altar da Matriz de Sabará, onde deveria ser colocada uma imagem de Nossa Senhora do Carmo que havia sido encomendada ou para 
serem utilizados naquilo que os irmãos achassem mais necessário; uns brincos e um laço de diamantes que possuía, para o ornato da imagem; 200.000 réis para ajudar na pintura do corpo da Matriz; 30.000 réis para o ornato do altar do Senhor dos Passos da Matriz; 30.000 réis para a compra de cera para se rezar o terço no altar de Nossa Senhora do Rosário; 60.000 réis para o ornato do altar da Capela de Nossa Senhoa do Ó de Sabará; 30.000 réis para o ornato do altar do Senhor São José, de quem era devota, na Matriz; 400.000 réis para ajudar seu sobrinho, o Doutor João Baptista Lopez, a se ordenar; 400.000 réis para ajudar outro sobrinho, Thomaz de Faria, a se ordenar; 100.000 réis para os lugares santos de Jerusalém; 100.000 réis para as obras do convento de São Francisco, em Lisboa e 100.000 réis para o vigário da freguesia, que deveria distribuí-los entre pessoas pobres. ${ }^{27}$

O inventário dos bens dos testadores também revelam aspectos interessantes da vida cotidiana. Entre as mulheres foi mais comum o arrolamento de utensílios domésticos e jóias, enquanto que os bens imóveis, as roupas, os créditos e os escravos eram relacionados por testadores de ambos os sexos.

As mulheres, sobretudo as libertas, possuíam freqüentemente tachos e bacias de cobre usadas para fazer doces, garrafas e copos de vidro e, em alguns casos, chocolateiras. As jóias mais comuns eram os cordões de ouro e brincos de ouro e pedras e, ainda, grande quantidade de corais, quase sempre engranzados em ouro e em prata. ${ }^{28}$ Já entre as vestimentas, eram muito citadas as saias de seda e de baeta e as camisas de linho e de bretanha.

Note-se que a posse daqueles utensílios domésticos esteve associada, em muitos casos, às atividades comerciais — vendas e tabuleiros — desenvolvidas pelas mulheres forras ou por suas escravas. Em relação às jóias e a outros valores —ouro em pó e objetos em metal e pedras preciosas- é importante ressaltar que foram frequentemente empenhados, fazendo parte de um eficaz e generalizado sistema de créditos e débitos, integrado por forros e livres de ambos os sexos. Este fato evidencia a monetização do universo mineiro colonial.

O mais importante de todos os bens era, contudo, o escravo. Neste aspecto, os testamentos são fontes de grande valor, uma vez que trazem,

27 APM/CMS - códice 24, f.27v. Testamento de Izabel Moreira de Castilho - Sabará 18 SET 1756.

28 Sobre essas jóias, que eram, também, amuletos, ver Paiva, Eduardo França: Escravidão ... págs. 217-238. 
quase sempre, a identificação de cada cativo, seu nome e sua origem. Mais raramente eram indicados a idade aproximada, a filiação, o estado civil, o nome dos filhos e as características pessoais de cada um. Além disso, os testadores registravam as alforrias e coartações, assim como as condições exigidas para efetivá-las. Em alguns casos, os proprietários procuraram dar rumo à vida de seus escravos após receberem suas cartas de alforria, através de legados materiais previstos nos testamentos. Houve libertos que herdaram moradias, instrumentos e condições de trabalho.

Facilitado o acesso aos meios de produção, vários escravos construíram e gerenciaram suas fontes de rendimento, o que garantiu para uns a efetivação da alforria e para outros o início de um processo de libertação. $\mathrm{Na}$ verdade, essas práticas são expressões da complexidade, da mobilidade e da dinâmica experimentadas naquela sociedade intensamente urbanizada, de economia pujante e diversificada, onde escravos e escravas exploraram, em proporção jamais vista, as incontáveis possibilidades geradas nas negociações cotidianas, tais como as coartações e o ganho. ${ }^{29}$

A terceira parte dos testamentos prima, talvez em maior grau que as anteriores, pela riqueza informativa. Tal característica não se repete, porém, nas duas partes finais. Na quarta parte finaliza-se formalmente o texto através de disposições operacionais — prazo dado ao testamenteiro para cumprir cada item exposto, aprovação e abertura- e das assinaturas.

Os codicilos, por sua vez, não eram comuns. Quando registrados tinham por objetivo alterar legados ou disposições anteriores, embora não tenham representado modificações profundas nos textos originais.

Não obstante a divisão dos testamentos aqui adotada, é necessário observar a existência de algumas questões que fugiam às características de cada parte e não tinham localização determinada a priori. Trata-se, sobretudo, de confissões ou de desvelamentos cujos conteúdos, em alguns casos, parecem ter sido minimizados pela agonia e pela morte. Noutros casos, reconhecer faltas e tornar conhecidas algumas intimidades, podem ter objetivado o perdão humano e divino, bem como a manutenção na memória coletiva de uma imagem ou de um perfil que se desejou duradouro.

29 As coartações já foram explicadas antes. Já o ganho, era um acordo estabelecido entre as partes para que os escravos pudessem trabalhar nas ruas das áreas urbanas, oferecendo vários tipos de serviço e prestando contas ao final do dia, da semana ou do mês aos proprietários. Nos dois casos observa-se muita mobilidade e, também, práticas que se transformaram em direitos costumeiros. Ver sobre os temas Paiva, Eduardo França: Escravos ... e Paiva, Eduardo França: Escravidão .... 
Como escreveu Walter Benjamim, "a morte é a sanção de tudo o que o narrador pode contar". ${ }^{30} \mathrm{O}$ testador é também um narrador e, neste sentido, utiliza-se de seu texto de morte como instrumento difusor de sua narrativa. As expressões mais importantes e, também, as condições cotidianas de uma convivência material, espiritual e intelectual, encontram-se registradas nos testamentos. É certo que a utilização destes documentos requer a avaliação de seu alcance social, isto é, o conhecimento de seus limites enquanto fontes históricas e de sua representatividade em relação a uma sociedade complexa, como foi a desenvolvida em Minas Gerais durante o Setecentos.

Uma vez identificada a potencialidade dos testamentos para o estudo do universo colonial, cabe à leitura crítica do historiador o aproveitamento do conjunto de informações daí provenientes. Muitas vezes, entretanto, a análise associada de testamentos e de inventários post-mortem potencializa os estudos sobre as sociedades coloniais. Os documentos, embora complementares e de natureza semelhante, não trazem, contudo, as mesmas informações. Os inventários são, por assim dizer, registros mais áridos sobre as formas de viver naquelas sociedades. As informações, no geral, mais objetivas, possibilitam interpretações baseadas em dados quantitativos. A vida material aparece explicitamente nesses registros e, de maneira semelhante, vêm agregados os valores monetários atribuídos aos objetos e aos bens, tantos imóveis, quanto móveis. Certamente, o conjunto de informações testamentais torna-se muito mais rico quando a ele se agrega os dados inventariais.

Para escrever esse texto usei dados e informações qualitativas retirados de testamentos e inventários post-mortem de homens e mulheres livres e forros, de brancos, negros e mestiços, de naturais do Brasil, ${ }^{31}$ portugueses, africanos de variadas regiões, além de outras origens. No total, o conjunto é composto de seiscentos e oitenta testadores e inventariados, responsáveis pela elaboração de milhares e milhares de folhas escritas na frente e no verso. A data mais antiga é 1716 e a mais recente é 1789. Ao final, o conjunto selecionado abrangeu oito décadas do Setecentos e extensa região

30 Benjamin, Walter: "O narrador ... “, pág. 208.

31 Doravante, por homens e mulheres naturais do Brasil entenda-se nascidos na Colônia. Não se trata, evidentemente, de um emprego anacrônico da nacionalidade brasileira, que, de resto, só seria forjada no século XIX. Também não se trata de designação usada para os que nasceram no território do Estado do Brasil, diferenciando esses homens e mulheres dos nascidos nas terras do Estado do GrãoPará e Maranhão. 
da capitania das Minas Gerais. E, de uma forma ou de outra, todos os seguimentos da população encontravam-se representados nos documentos. Entre os testadores e inventariados escolhidos os homens brancos portugueses, portanto livres, conformam o maior grupo. Ao contrário do que se pode pensar inicialmente, deixam muitos e importantes esclarecimentos sobre a vida da população escrava, principalmente sobre as posses individuais de cativos e sobre as relações estabelecidas com os respectivos proprietários. Informam, também, sobre alforrias, explicitando mecanismos de dominação empregados e, sem querer, deixando escapar detalhes indicadores de estratégias de resistência empregadas pelos mancípios. Ajudam muito, ao registrarem seus valores primordiais, suas visões de mundo, seus costumes e seus códigos de comportamento, uma vez que tudo isso foi apropriado pelos escravos e pelos libertos, que, por seu turno, os incorporaram inteiramente ou imprimiram-lhes adaptações e releituras ou mesmo os reconstruíram. Assim, foi possível comparar o uso desses traços culturais pelos dois agrupamentos e vislumbrar a dimensão social alcançada nesse jogo de imposições e enfrentamentos.

As mulheres forras contribuem com o segundo maior volume documental. Juntas com os homens forros, oferecem, também, relatos e informes de importância ímpar para a melhor compreensão dos relacionamentos sociais engendrados, de suas posturas, condutas e representações culturais, de suas atividades econômicas e de seu consumo material. Foi possível, ainda, examinar as relações mantidas com seus escravos e exescravos e com outros forros. Em vários documentos ficaram registradas as maneiras pelas quais conseguiram suas manumissões, revelando-se, por vezes, os valores pagos e as formas de pagamento.

A documentação investigada acabou oferecendo muitas respostas às indagações dirigidas a ela. A todo instante emergiu desse diálogo a necessidade de não me esquecer que os principais personagens deste trabalho viveram, pensaram, agiram e morreram no século XVIII. Homens e mulheres filhos de seu tempo, portanto imbuídos de valores, portadores de demandas, agentes de idéias, protagonistas de histórias daquele tempo, gente que, no dia-a-dia, transformou a rigidez de fronteiras idealizadas em tênues referências, muito facilmente e muito comumente transpostas. Não são invenção ficcional, embora renasçam através de um olhar historiográfico de outra época, imbuído, ele também, de marcas de seu próprio tempo. Releitura do passado feita sempre no presente. Viagem no tempo: mágica da História e razão de seu fascínio. 


\section{Relatos femininos - Minas Gerais, Brasil, século XVIII}

Innocencia de Siqueyra Tavora, criola forra (APM/CMS, ${ }^{*}$ livro 20, fs 70v-72 - 07/01/1745 - Sabará)

Innocencia declarava ser natural do Rio de Janeiro, nunca ter sido casada, mas ter uma filha "que houve no tempo que ela era cativa de Felippe Soares, e por esta razão ficou ella dita minha filha ficando cativa do dito senhor de cujo poder a mandei libertar, ou mandei o dinheiro para isso por ella mo mandar pedir"

"Declaro que a minha filha Antonia Gonçalves acima declarada estando em poder de seu senhor ainda captiva me escreveo varias vezes lhe mandase o dinheiro para haver de se libertar; e compadecendo-me della the mandei duzentos, e quarenta mil reis para sua liberdade, a qual quantia mandei por modo de emprestimo, e como vindo para estas minas não quis acomodasse comigo em minha companhia, mas se auzentou de mim para donde não tenho noticias della."

Izabel da Rocha, parda forra (APM/CMS, livro 20, fs.113v-114v 03/03/1754 - Sabará)

Declara possuir "huas moradas de cazas terrias com seu quintal citas na rua de cima da Igreja grande desta villa que partem, de hua parte com cazas do Capitão Mor (...) cujas cazas acima deixo pelo amor de Deos de esmolla a Thomazia parda forra que foi minha escrava de cuja alforria estou paga e na mesma forma deixo também as dittas cazas a Efigenia cioulla irmã da dita mulata digo da dita Thomazia para ambas viverem nas ditas cazas as quais lhe fica pertencendo a cada hua a metade das ditas cazas que pello amor de Deos lhes deixo para o que serão as ditas legatarias obrigadas digo acima nomeadas obrigadas a pagar a irmandade do Santissímo Sacramento dessa Matriz trinta mil reis, os quais lhe pagarão dentro do tempo de quatro annos."

Luiza Rodriguez, criola forra (APM/CMS, livro 24, fs. 110-111v 21/12/1754 - Sabará)

Luiza declarou ser solteira e ter havido uma filha chamada Maria "que indo para o reino faleceo há bastante annos". Luiza era "filha de huma preta Apolonaria já defunta (...) e sendo escrava de Francisco Ventura Pinto morador nas Geraes me forrey por duzentas oitavas." 
"Declaro que posuo huma escrava por nome Leonor que houve por titullo de compra a Manoel Teixeira Coelho que lhe pasey (?) carta (?) de obrigação, e de todo o tempo me fazer boa, e me por apóz e a salva da demanda que corre sobre ella com Ignacia de Tal mulata da tal negra tem hoje tres crias, hum por nome Agostinho, e outro de peito por nome Manoel que se venderão por meo testamenteiro a quem por elles mais der, e o outro filho da dita negra hé forro e se chama Jozé, que o criey e lhe passey carta de alforria que se haja em meos papeis, e se emtregara com a mesma crioula a sua madrinha Flor Rodrigues que taobem criey a qual pesso pello amor de Deos o crihe sustente, e vista lhe [? ]apreender hum ofício aquelle que elle se inclinar, e o mesmo crioulo a sirvira emquanto não poder ganhar pello oficio que aprender, e se sustentar e vistir e não o fazendo assim pesso de merse a meo testamenteiro o faça a custa da minha fazenda."

"Declaro que posuo alguns moveis de caza, e alguma roupa de meo uso dos quais todos os que se acharem deixo pello amor de Deos a dita Flor Rodrigues."

Luiza da Souza, parda forra (APM/CMS, livro 20, fs.124v-126 30/08/1755 - Sabará)

Luiza era viuva de Zacarias Tavares com quem não havia tido filhos. Entretanto, antes de casar com Zacarias, declarava ela, ter tido sete "filhos e filhas dous falecerão e sinco que não sei se estão vivos todos, que são Anacleto da Sylva ja casado, Francisco da Sylva de idade de 30 annos, e tenho noticia esta cazado no sertão, Joanna cazada no sertão que inoro (sic) o nome do marido da dita minha filha Maria e Simoa cujas duas minhas filhas tive no tempo que era cativa de Francisco Gomes Ribeiro este como senhor das ditas minhas filhas Maria e Simoa as vendeo, e me não lembra a quem, tenho feito grandes diligencias e procuralas e não tenho dellas achado noticias e assim cazo que apareção são também minhas erdeiras forçadas, que erdarão em igual parte com as outras asima a saber Nacleto da Sylva e Joanna."

Andreza Martinz Cardoza (APM/CMS, livro 24, fs.36-38v - 04/10/1758 - Arraial do Pompéu)

Andreza não declarou sua origem, nem seu estado civil e se tinha filhos. Declarou, entretanto, possuir "hum negro por nome Manoel de nação 
Mina o qual deixo quartado em cento e cincoenta oytavas. Item declaro que posuo huma negra por nome Joanna de nação Mina a qual deixo quartado em sesenta e quatro oitavas de ouro. Item declaro que possuo huma negra por nome Roza de nasção Mina a qual deixo quartada em duzentas e cincoenta e seis oitavas de ouro [ ? ]de sua Magestade assim [ ?] sua [ ? ] que a dita [ ? ] escrava por nome Roza lhe não admitão a avaliação alguã atendendo ao grande beneficio que fiz em lhe forrar tres filhos e sem deles receber cousa alguma a saber hum mulato por nome Antonio e huma crioula por nome Josefa e outra crioula por nome Felipa serão os ditos escravos asima nomeados a [ ? ] todos os annos a fazer hu pagamento por anno em seis annos [?] o que lhe [?] conforme os seus cortes e meus testamenteyros recebida a dita coantia lhe passarão a sua carta de alforria."

"Item declaro que tenho duas moradas de cazas sitas neste arraial do Pompeu huma em que uso a qual morada em que vivo com seu quintal que lhe pertence deixo aos meus escravos a saber huma creoula por nome Antonia e outra Jozefa e outra Felippa e hum mulato Antonio e huma negra Antonia digo negra Joanna e outra Rosa e o negro morarem digo e o negro Manoel para todos morarem as ditas casas e serem senhores dellas para morarem e dato (sic) cazo que algum queira sair da dita caza não terá jus nem direito algum na dita casa e perderá todo o dominio nella e não se poderão vender."

Andreza declarou, ainda, estar "em meu poder", ouro lavrado pertencentes a outras pessoas, o qual se encontrava penhorado em sua mão. Alertava, assim, seu testamenteiro, que se os donos do ouro pagassem o valor do penhor ele deveria devolvê-lo.

Maria do Nascimento Sylva (APM/CMS, livro 24, fs $81 \mathrm{v}-83 \mathrm{v}$ 02/07/1761 - Sabará)

"Item declaro que he minha vontade que se minha criolla por nome Bonifacia dentro de tres annos depois da minha morte der para a sua alforria e para a de sua filha Genoveva huma livra de ouro meu testamenteyro este depois de receber a dita libra de ouro lhe passara carta de alforria tanto della como a sua filha Genoveva pois he minha vontade que fique ella Bonifacia e mais sua filha Genoveva ambas cortadas neste [?] meu testamento em huma libra de ouro e meu testamenteyro cada dous meses tomara contas a dita minha crioulla Bonifacia para sua alforria. Item declaro que a minha negra Caetana a quartey em duzentas oitavas digo em duzentos mil 
reis e lhe dey tres annos para procurar ouro para sua alforria os quaes já se findarão como melhor constará do escrito da licença que lhe dey e como ainda não estou satisfeita de toda a quantia das duzentas oitavas mando ao meu tetamenteyro lhe tome contas assim que eu morrer e lhe leve em conta todos os recibos que ce tiverem no mesmo escripto da licença depois de tomar a dita minha negra Caetana as contas lhe dará mais licença por tres mezes para ella dar o resto digo licença por tres meses para satisfazer o resto que quando ainda no tempo de tres mezes não [?] e ajustar as duzentas oytavas em a cortey meu testamenteiro lhe não concederá mais tempo mas sim uzará do direyto que ouver neste cazo e se ella nos tres mezes que a lhe concedo ajustar a conta das duzentas oytavas dando recibo que dellas deve meu testamenteyro estão lhe passara sua carta de alforria."

"Declaro que nomeyo e instituo por minha erdeyra universal de tudo o que depois de pagas minhas dividas, e cumpridos os meus legados restar da minha fazenda nomeyo e instituo por minha universal erdeyra digo por minha erdeyra universal a huma molatinha que tenho em minha companhia por nome Ignes a quem sempre tratey com amor de may e atendendo o grande amor que sempre tive peço encaricidamente a meu testamenteyro que logo que eu morrer tome conta della pondo-a em huma caza onrada a eduacar-se athe ter idade de tomar o estado de cazada que lhe procurará dar meu testamenteyro com hum homem branco ainda que pobre declaro que a minha erdeyra chama-se Sebastiana Ignés [?] he a quem nomeyo por minha erdeyra universal"

"Deyxo a huma crioulinha por nome Joanna filha da minha crioula Bonifacia se proceder bem quando estiver para tomar estado de cazada declaro que tenho ao prezente huma saya de camellão e oito varas de lagem [ ? ]."

Codicilo da mesma testador, Sabará, 15/07/1761

"Declaro e ordenno a meu testamenteiro que a minha negra Caetana a quem dey no meu testamento maes dous mezes para dar o resto da sua alforria por se ter acabado o tempo se tres annos que ja lhe tenho concedido para buscar ouro para sua alforria quero e mando ao dito testamenteyro lhe de licença por hum anno para dar o resto que dever para sua alforria com as condisões do meu testamento por que só aqui lhe concedo tãobem [ ? ] de hum anno pelos dous mezes que lhe concedia no meu testamento e assim [ ? ] declaro que no meu testamento deyxei a minha crioulla Bonifacia com a filha Genobeba ambas quaretadas em huma libra de ouro por tres annos e aqui hey por derrogada esta disposição a qual ordeno na forma seguinte." 
Marianna do Rego Barros, parda forra (MR/INV, ${ }^{*}$ cx. 30, fs.4-8 10/09/1760 - Vila de São José)

Declarou que era natural da Freguesia de Santo Antonio do Cabo, do bispado de Pernambuco, que era parda forra, que teve uma filha, já falecida, Luzia da Costa, que se casara em Goiás, com Antonio de Andrade, e que lhe ficaram duas netas, Angelica e Maria, que eram suas herdeiras necessárias.

Declara possuir (...) "hum escravo preto Banguella chamado Manoel, huma escrava preta mina chamada Antonia e huma escrava crioula chamada Maria, e algumas roupas e trastes comuns de caza de muito pouco valor. A dita minha escrava preta mina chamada Antonia, dexo quartada pello preço de sinco quartas de ouro.” A escrava coartada deveria entregar seu valor aos testamenteiros, no tempo de um ano e meio, com a condição de dar fiador dentro de dois meses após seu falecimento, e de se obrigar a pagar as cinco quartas de ouro à testamentaria, caso a dita preta não paguasse dentro do prazo ou caso falecesse. Determinava que quando seu testementeiro recebesse a quantia, passasse logo carta de alforria. Também deixava coartada sua escrava crioula chamada Maria, pelo preço de meia libra de ouro, pelo mesmo tempo de um ano e meio, debaixo da mesma condição de dar fiador e com as mesmas cláusulas declaradas para a preta Antonia.

Era sua vontade que se lançasse na terça parte do monte que lhe pertencia as suas casas pequenas, que partiam com as casas onde morava, incluindo todas as roupas e trastes de casa, exceto as peças de ouro. Deixava a casa com os trastes, por legado, à sua sobrinha Maria de Barros e a Marianna Correa, que moravam com ela.

Pelonia Pedroza de Brito (MR/INV, cx. 37, fs.9-18 - 25/04/1758 - Pouso Alto)

"Primeiramente encomendo e rogo a meu marido Antonio da Silva, Manoel Rodrigues da Foncequa e a Domingos Pereira da Silva que por serviço de Deos queirão ser meus tetamenteiros, ordeno que meu corpo seja sepultado na porta da igreja da parte de fora atrabessado e amortalhado a meu corpo no abito de São Francisco, e se me dirá hum officio de corpo presente [?] minha se me dirão quarenta missas huma de corpo presente." 
Barbara Gomes de Abreu e Lima, crioula forra (MO/CPO/TEST, ${ }^{*}$ livro 2, fs. 86v-91 - 12/07/1735 - Sabará)

Declarou "que me forrey nestas Minas e que por direito não tenho herdeiro forssado porque nunca fuy cazada e hum filho que tive he falecido."

Bens: "seis cordoens pesando cento e hua oitavas, hum se acha empenhado na mão de Thereza de Jezus, molher de Antonio Alves por vinte oitavas e trez na mão de Joze Ferreira Brazam donde se achao dous cordoens em mendados que fazem hum, quarenta oitavas, hum cordão com hua aguia, hum pente, hua estrela, hua argola solta, hum coração, tudo em ouro, também empenhado na mão de Joze Ferreira Brazam, hum cordão de ouro, hum feitio de menino Jesus de ouro pesando cinco oitavas, huas argolinhas de ouro pesando quatro oitavas, hua senhora de feitio de Nossa Senhora da Conceição pesando três oitavas e meia, huns brincos de aljofar e huns botoens de ouro, huas argolinhas de ouro pequenas, hua bola de ambar, uma bolta de corais engranzados em ouro, hum coral grande com hua figa pendurada tudo de ouro, quatro colheres de prata pesando oito oitavas cada hua, quatro garfos de prata e hua faca com cabo de prata, duas memórias de emberessadeiras, dous pares de botoens de enagoaz abertos no buril, tudo empenhado na mão de Manoel de Magalhaens por sete oitavas, o que meus testamenteiros desempenharam. Item tenho empenhado mais hum cordão de ouro com o peso que se achar na mão de Joze Rodrigues de Souza por vinte oitavas que meus testamenteiros desempenharam. (...)"

"hua morada de cazas em que vivo no largo da Igreja grande e defronte da Igreja Matriz desta villa as quais houve por titullo de compra que della fiz a Domingas Ferreira de Souza hum tacho grande de cobre e outro pequeno doze pratos de estanho e dous grandes, huns corais, quatro saias, duas de seda preta e hua de rossa grana parda e uma de camellao carro de ouro e a roupa branca que se achar e das duas sayas de seda preta se dara huma dellas a Thomazia molher branca e velha pello amor de Deos três panos de dous covados, hum preto, hum azul e hum verde, um colchão de lã Thereza, Inacia e Anna minas Clara criolinha Manoel criolinho Lionel criolinho o qual corto em presso de vinte e cinco oitavas que dando as seos padrinhos ou outra qual quer pessoa lhe passaram meos testamentos carta de alforria Maria criolinha." 
Francysca Poderoza (MO/CPO/TEST, livro 13, fs.90v-95v - 06/08/1742 - Pitangui)

Declarou ser "filha natural de Pascoal Homem e Moxia Carijo e baptizada na freguesia de nossa senhora da Candelaria da dita Villa de outú com o nome de Anastacia e coando me crismey nesta villa modey o nome de Anastacia em Francysca."

Bens: "hua casa de capim na gouveira a metade do citio de tras do morro desta villa me pertence por fabricar junto com Domingos Macial Aranha onde tenho huma caza de capim..."

Felicia Ferreira, criola forra (MO /CPO/TEST, livro 52, fs.45-51 03/01/1776 - São Miguel do Termo de Caeté)

"e em mão e poder de Francisco Pereira de Mello por eu ser captiva do dito este me passou meu papel de quartamento para ser forra pello preço e quantia de duas livras de ouro que sam duzentas e sincoenta e seis oitava e como eu do meu trabalho saptesfis a dita quantia mencionada se me passou a minha carta de alforria e me acho forra pella merce de Deos."

"passo nomear por meus herdeiros de minha fazenda, e só sim pellas muitas obrigaçoens que tenho e de criação nomeyo e instituo por meus herdeiros das duas partes de meus benz em igual parte cada hum a Joaquim Correa e seu irmão Vecentte Correa filhos legitimos de Antonio Correa Rego já deffunto e de sua mulher Eugenia Gomes de Macedo ambos moradores na freguesia de Sam Miguel..."

Bens: "huma rossinha que possuo eu a tem um payol pequeno em que se recolhe algum milho (...) se acha junto ao arrayal de Sam Miguel a deyxo com todos os seus pertences a Manoel da Guerra para pagamento do que ao dito devo..." 